\title{
Rapid and Mild Synthesis of Au-NHC Complexes in a Simple Two-Phase Flow Reactor
}

\author{
Helgi Freyr Jónsson, Anne Fiksdahl and Andrew J. Harvie
}

Department of Chemistry, Norwegian University of Science and Technology, 7491 Trondheim, Norway

e-mail: andrew.j.harvie@ntnu.no, helgi.f.jonsson@ntnu.no

\begin{abstract}
We describe a simple two-phase flow reactor which allows for the efficient and rapid synthesis of several $\mathrm{Au}(\mathrm{I})-\mathrm{NHC}$ complexes under mild conditions, with minimal workup, and avoiding common problems with decomposition to $\mathrm{Au}(0)$. An optional second stage allows for direct synthesis of $\mathrm{Au}(\mathrm{III})-\mathrm{NHC}$ complexes, without isolation of the $\mathrm{Au}(\mathrm{I})-\mathrm{NHC}$ intermediate.
\end{abstract}

\section{Introduction}

$\mathrm{N}$-Heterocyclic carbenes (NHCs) are one of the most widely used classes of ligands for organometallic complexes. The strength of the metal-carbene bond as well as the ease of modification of both the backbone as well as the $\mathrm{N}$-wingtip substituents make this ligand class especially attractive. ${ }^{1,2} \mathrm{NHC}$ complexes of gold have been shown to catalyse a wide variety of reactions, and $\mathrm{Au}(\mathrm{I})-\mathrm{NHC}$ complexes especially are important in gold catalysis. ${ }^{3,4} \mathrm{Au}(\mathrm{III})$ has found considerably less use than $\mathrm{Au}(\mathrm{I})$-NHC complexes, despite being readily available from the $\mathrm{Au}(\mathrm{I})$ precursors by a simple oxidation. This is most likely due to $\mathrm{Au}(\mathrm{III})$ 's propensity towards reduction to $\mathrm{Au}(\mathrm{I})$ or $\mathrm{Au}(0)^{5}$. Both $\mathrm{Au}(\mathrm{I})$ - and $\mathrm{Au}(\mathrm{III})-\mathrm{NHC}$ complexes have also shown promise as anticancer agents and their potential application in medicinal chemistry has been widely studied. ${ }^{6}$

There are three main methods to synthesise $\mathrm{Au}(\mathrm{I})-\mathrm{NHC}$ complexes; the free carbene route (Scheme 1a), the transmetallation route (Scheme 1b), and the weak base route (Scheme 1c). ${ }^{7}$ All the routes start with the imidazolium chloride salt 1 and a gold precursor with a labile ligand, such as $\mathrm{Me}_{2} \mathrm{SAuCl}$. Both the free carbene route and the transmetallation route suffer from several disadvantages. In the free carbene route, generation of the carbene requires a strong base, such as KHMDS, $n$-BuLi, or NaH. Additionally, the instability of the free carbene makes rigorously inert conditions a necessity, usually requiring the use of a glovebox. The transmetallation route, on the other hand, requires the synthesis of either the $\mathrm{Ag}(\mathrm{I})$ - or $\mathrm{Cu}(\mathrm{I})$-NHC complex ahead of time. The higher cost and lower atom economy of this reaction route, as well as the light sensitivity of $\mathrm{Ag}(\mathrm{I})-\mathrm{NHC}$ complexes are significant downsides.

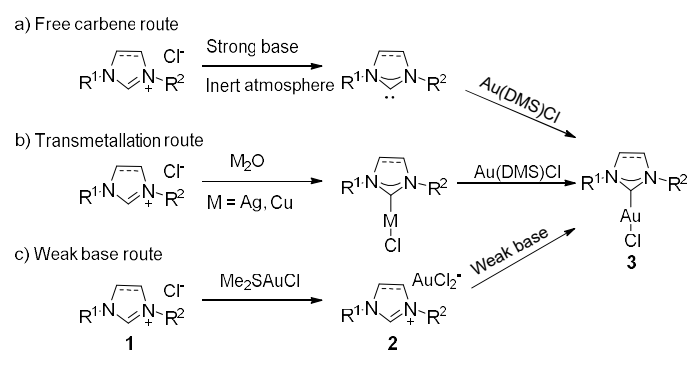

Scheme 1. Synthetic routes towards Au(I)-NHC complexes.

The weak base route has in recent years shown to be an easy and efficient alternative to synthesise $\mathrm{Au}(\mathrm{I})$-NHC complexes. The use of weak, inexpensive bases such as $\mathrm{K}_{2} \mathrm{CO}_{3}, \mathrm{NEt}_{3}$ and $\mathrm{NaOAc}$, alongside DCM or acetone as the most common (singlephase) solvents, all under ambient atmospheric conditions makes this route attractive. 8,9

Mechanistic studies indicate that the reaction proceeds via an aurate intermediate $\mathbf{2}$, which is formed rapidly by displacement of $\mathrm{Me}_{2} \mathrm{~S}$ by the chloride anion upon mixing of the imidazolium chloride 1 and the $\mathrm{Au}(\mathrm{I})$ precursor. These aurate salts are generally stable, and selected examples have been isolated and fully characterised. ${ }^{10,11}$ The Au(I)-NHC complex 3 formation is then postulated to go through a concerted metallation-deprotonation process, at least when $\mathrm{NEt}_{3}$ is used as the base. Spectroscopic evidence indicates that the free carbene is not generated during the reaction. ${ }^{12}$ As these reactions are typically performed in a single solvent phase over an insoluble base, workup involves at least one filtration step. Additionally, the long reaction times which are often required result in the reduction of some of the $\mathrm{Au}(\mathrm{I})$ precursor to $\mathrm{Au}(0)$, potentially harming reaction yields and complicating workup. 
We have recently reported a study on alcohol functionalised $\mathrm{Au}(\mathrm{I} / \mathrm{III})$-NHC complexes, which were synthesised via a modified, two-phase version of the weak base route. ${ }^{13}$ Compared to a typical reaction performed in a single DCM phase, we found that performing the reaction in a two-phase DCM: $\mathrm{H}_{2} \mathrm{O}$ system sped up the reaction significantly; full conversion was usually observed in under 2 hours, compared to only $35 \%$ after 12 hours in the single-phase system. However, in that batch process, we still noted a significant presence of $\mathrm{Au}(0)$ contamination, requiring filtration of the product through a silica plug to acquire the pure $\mathrm{Au}(\mathrm{I})-\mathrm{NHC}$ complexes.

Droplet-based microfluidic flow reactors offer several advantages over batch reactors for performing multiphase reactions. In two-phase chemistry, reaction rates are often limited by the interfacial area (per unit volume) between the two phases. By splitting the phases into microlitre-scale droplets in intimate contact, this interfacial area-to-volume ratio is typically much greater than in an equivalent bulk reaction, greatly increasing the amount of phase mixing. Additionally, as each droplet is generated identically (at least for stable flows), mixing and heating are highly reproducible, avoiding much of the batch-to-batch variation typical of batch processes. ${ }^{14}$ This property of flow reactors is also beneficial during scale-up; in batch processes, scale-up requires use of larger reaction volumes, reducing the contacting surface area between phases, as well as larger reaction vessels which exhibit different heat transfer characteristics. In a flow reactor, however, the reaction can simply be run for longer. For larger scale-ups, the reaction stream can simply be split into multiple parallel streams, each with the same flow conditions as the reaction optimised at the smaller scale. For two-phase batch reactions, phases are generally manually separated using a separation funnel or the like, whereas flow reactors can make use of simple in-line separators that perform this step without requiring human input. ${ }^{15,16}$ This reduces the amount of workup that must be performed manually, but is also particularly useful for multi-step reactions where new reagents need to be added to the reaction volume downstream. Two-phase flow reactions can also be performed in very simple flexible tubes. This is not only cost effective, but is convenient for temperature control, as the reaction temperature can be controlled by submerging the tube in a standard water bath. ${ }^{17}$

Simoens et. al. have recently reported a methodology using a continuous flow solid-phase reactor for the synthesis of $\mathrm{Au}(\mathrm{I})-\mathrm{Cu}(\mathrm{I})$ - and Pd(II)-NHC complexes using the common ligand IPr. ${ }^{18}$ They achieved impressive yields of up to $93 \%$ for the $\mathrm{Au}(\mathrm{I})$-IPr complex, using short ( $2 \mathrm{~min}$ ) residence times. However, solid phase flow reactors suffer from several disadvantages when compared to liquid-liquid reactors. Solid-phase reactors generally require the solid phase to be replenished between each experimental run, which can be laborious. Additionally, solid-phase reactors are susceptible to poisoning of the packed solid phase, which can greatly reduce the reactor performance. This is a particular issue for gold chemistry, due to gold's propensity for forming nanoparticles. ${ }^{18}$ Liquid-liquid reactors suffer from no such issues: preparation of the reactor generally consists of simply loading reactant solutions into pumps, and a reactor can be immediately reused after flushing with a suitable solvent.

With these advantages in mind, we explored the synthesis of several $\mathrm{Au}(\mathrm{I})$-NHC complexes in a simple two-phase flow reactor, with the aim of improving the total reaction time and simplifying workup. This is, to the best of our knowledge, the first example of a segmented flow reactor being used for the synthesis of metal-NHC complexes.

\section{Results and discussion}

A schematic of our liquid-liquid flow reactor is shown in Figure 1. Matched syringes containing an aqueous base solution (S1) and a DCM solution of the relevant NHC-aurate $2 \mathrm{a}-\mathrm{g}(\mathrm{S} 2)$ are connected to the inputs of a $\mathrm{y}$-shaped mixer (Y1, see Fig S1 in $\mathrm{SI}$ ), and mounted within a dual-channel syringe pump. The co-injection of immiscible liquids at a stable flow rate into $\mathrm{Y} 1$ generates a stable, uniform segmented flow, which is directed into a $5 \mathrm{~m}$ length of coiled tubing (Zone $\mathrm{A}$ ) where the aurate intermediate in the DCM reacts with the aqueous base, forming the desired Au(I)-NHC complex 3a-g. The tubing in Zone $A$ is held at $35{ }^{\circ} \mathrm{C}$ by submersion in a temperature-controlled water bath. For all experiments listed here, the flow rate of each solution was held at $200 \mu \mathrm{l} / \mathrm{min}$, yielding a total flow rate in Zone $A$ of $400 \mu \mathrm{l} / \mathrm{min}$. The internal diameter of the tubing in Zone A was $1 \mathrm{~mm}$, which corresponds to a total internal volume of $3.925 \mathrm{ml}$. At a total flow rate of $400 \mu \mathrm{l} / \mathrm{min}$, the total transit time within Zone A is $9.8 \mathrm{~min}$. The segmented flow exits Zone A into a previously-described liquid-liquid phase separator PS (see Fig S2 in SI), which physically separates the two phases and stops the reaction. ${ }^{16}$ The DCM phase, which contains the newly formed $\mathrm{Au}(\mathrm{I})-\mathrm{NHC}$ complex, is collected for analysis by ${ }^{1} \mathrm{H} \mathrm{NMR}$, whereas the aqueous phase containing the partially depleted base is discarded as waste. Prior to ${ }^{1} \mathrm{H}$ NMR analysis, the solvent was simply removed under reduced pressure, and the crude product redissolved in deuterated chloroform. 


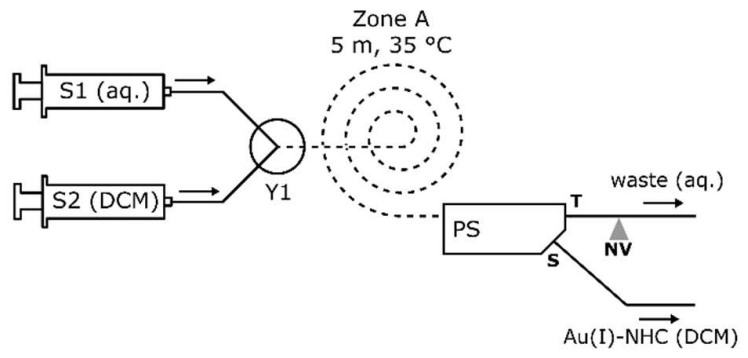

Figure 1. Schematic of flow reactor used for synthesis of $\mathrm{Au}(\mathrm{I})$-NHC complexes. An aqueous base solution and a solution of an imidazolium aurate salt $\mathbf{2}$ in DCM are injected at equal flow rates into a y-shaped mixer (Y1) using a matched pair of syringes ( $\mathrm{S} 1$ and $\mathrm{S} 2$ ). The mixer generates a 1:1 segmented flow of the aqueous and DCM solutions, which enters a $5 \mathrm{~m}$ length of coiled tubing (Zone $\mathrm{A}$ ) where the aurate intermediate 2a-g in the DCM reacts with the aqueous base, forming the corresponding $\mathrm{Au}(\mathrm{I})-\mathrm{NHC}$ complex 3a-g. The segmented flow then enters a liquid-liquid phase separator (PS). The aqueous phase containing partially depleted base exits the separator at the through-port $\mathbf{T}$, then passes through a micro-metering needle valve NV, before being discarded as waste. The DCM phase containing the $\mathrm{Au}(\mathrm{I})-\mathrm{NHC}$ complex is collected at the side port $\mathbf{S}$.

A wide range of imidazolium-based salts 1a-g (Scheme 2) were chosen for this study. These include the two most

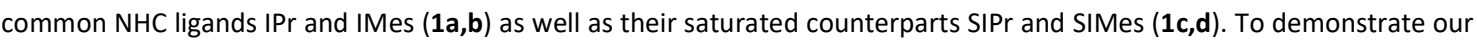
method on functionalised ligands we also included our previously reported alcohol functionalised imidazolinium salt $\mathbf{1 e}$. $\mathrm{Au}(\mathrm{I})$-NHC complexes with less hindered ligands are challenging to synthesise with the weak base method, ${ }^{19}$ so to test the scope of this method we chose $\mathrm{N}, \mathrm{N}$-dialkylimidazolium chloride $\mathbf{1}$. Additionally, to test if the efficacy of our method extends to a benzimidazolium motif, we also selected $\mathrm{N}, \mathrm{N}$-dialkylbenzimidazolium chloride $\mathbf{1} \mathbf{g}$, which has previously only been coordinated to gold via the free carbene route. ${ }^{20}$

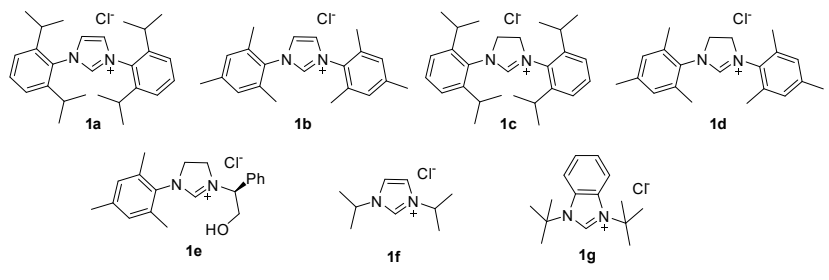

Scheme 2: Imidazolium-based salts 1a-g used in this study.

The azolium salts 1a-g were mixed with equimolar amounts of $\mathrm{Me}_{2} \mathrm{SAuCl}$ in DCM and sonicated to form $0.012 \mathrm{M}$ solutions of the corresponding aurate salts $\mathbf{2 a - g}$. The aurate solutions were then reacted under the segmented flow conditions described above with a $0.25 \mathrm{M}$ aqueous $\mathrm{K}_{2} \mathrm{CO}_{3}$ solution acting as base (Scheme 3 ). The results from the synthesis of the $\mathrm{Au}(\mathrm{I})$ complexes 3a-g are shown in Table 1.

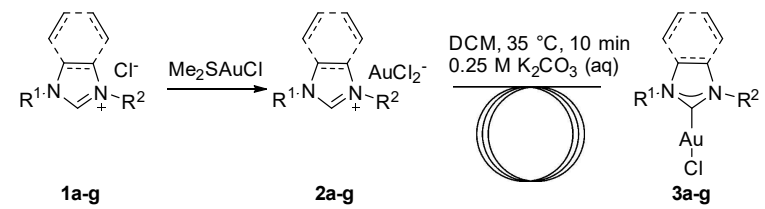

Scheme 3: Synthesis of $\mathrm{Au}(\mathrm{I})-\mathrm{NHC}$ complexes 3a-g in the segmented flow reactor described in Figure 1.

For imidazoli(ni)um salts 1a-e, with bulky aryl sidegroups, our conditions were extremely effective, giving full conversion to gold complexes 3a-e (Table 1, entries 1-5) and excellent yields ranging from $88 \%$ for $\mathbf{1 c}$ and $\mathbf{1 d}$, to $98 \%$ for $\mathbf{1 a}$ (compared with $93 \%$ reported for the same complex as synthesised with the solid-phase flow reactor of Simoens et. al.). It is worth mentioning that the only workup required was the evaporation of the organic phase under reduced pressure. This method is therefore well suited for the coordination of both imidazolium and imidazolinium chlorides, the latter of which have been reported to require longer reaction times. ${ }^{10}$

$\mathrm{Au}(\mathrm{I})-\mathrm{NHC}$ complexes with sterically unencumbered ligands are challenging to synthesise via the weak base route, usually showing decomposition to elemental gold. An exception is a method reported by Johnson et. al. which uses $\mathrm{NBu}_{4}(\mathrm{acac})$ as the base. ${ }^{19}$ To test our method on this type of substrate, we attempted the coordination of $\mathrm{N}, \mathrm{N}$-dialkylimidazolium chloride 1f. Unfortunately, this led to almost instantaneous formation of elemental gold (see Fig S3) and no complex was obtained (Table 1, entry 6). This method is therefore clearly not suited for less sterically hindered imidazolium salts, similar to most versions of the weak base route. Finally, $\mathrm{N}, \mathrm{N}$-dialkylbenzimidazolium chloride $\mathbf{1 g}$ was found to give only $38 \%$ conversion to $\mathrm{Au}(\mathrm{I})-\mathrm{NHC}$ complex $\mathbf{3 g}$ (Table 1, entry 7). We attempted to improve the conversion by changing the solvent to $\mathrm{CHCl}_{3}$, which 
allowed for an increase in temperature to $53^{\circ} \mathrm{C}$ (higher temperatures caused bubbles to form inside the tube). This led to an improvement in conversion to $76 \%$ (Table 1, entry 8), using the same residence time of 10 minutes. A further increase in conversion to $93 \%$ was observed by halving the flow rate and thus doubling the residence time to 20 minutes. However, at increased temperatures we observed significant decomposition of the gold complex which led to a greatly reduced yield of only $21 \%$ of the $93 \%$ pure $\mathrm{Au}(\mathrm{I})$-NHC complex $3 \mathrm{~g}$ (Table 1 , entry 9 ).

Table 1: Synthesis of Au(I)-NHC complexes 3a-g as shown in Scheme 3. ${ }^{\text {a }}$

\begin{tabular}{|c|c|c|c|}
\hline Entry & Preligand & Conversion to $\mathrm{Au}(\mathrm{I})-\mathrm{NHC} 3^{\mathrm{b}}$ & Isolated yield \\
\hline 1 & $1 a$ & $100 \%$ & $98 \%$ \\
\hline 2 & 1b & $100 \%$ & $90 \%$ \\
\hline 4 & 1d & $100 \%$ & $88 \%$ \\
\hline 5 & $1 \mathrm{e}$ & $100 \%$ & $94 \%$ \\
\hline 8 & $1 \mathrm{~g}$ & $76 \%^{d}$ & - \\
\hline 9 & $1 \mathrm{~g}$ & $93 \%$ d,e & $21 \%^{f}$ \\
\hline 10 & $1 a$ & $88 \%^{g}$ & - \\
\hline 11 & $1 a$ & $100 \%^{\mathrm{h}}$ & $95 \%$ \\
\hline
\end{tabular}

a $6 \mathrm{ml}$ of $0.012 \mathrm{M} \mathrm{DCM}$ solutions of aurates $2 \mathrm{a}$-g were reacted with $6 \mathrm{ml}$ of $0.25 \mathrm{M}$ aqueous solution of $\mathrm{K}_{2} \mathrm{CO}_{3}$ at $35^{\circ} \mathrm{C}$ in the flow reactor described in Figure 1 . ${ }^{b}$ Conversion determined by ${ }^{1} \mathrm{H}$ NMR spectroscopy. ${ }^{\mathrm{C}}$ Fast decomposition to elemental gold. ${ }^{\mathrm{d}} \mathrm{CHCl}_{3}$ was used as the solvent and the reaction temperature was increased to $53{ }^{\circ} \mathrm{C}$. ${ }^{\mathrm{e}}$ The flow rate was halved to $100 \mu \mathrm{l} / \mathrm{min}$ per syringe leading to a residence time of 20 minutes. f93\% purity according to ${ }^{1} \mathrm{H}$ NMR. ${ }^{8} 0.25 \mathrm{M}$

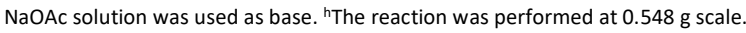

$\mathrm{NaOAc}$ has also been reported to be an alternative to $\mathrm{K}_{2} \mathrm{CO}_{3}$ for this reaction. ${ }^{21}$ We therefore attempted to synthesise complex 3a by using a $0.25 \mathrm{M}$ aqueous solution of $\mathrm{NaOAc}$ instead (Table 1, entry 10 ). This led to a reduced $88 \%$ conversion to $\mathrm{Au}(\mathrm{I})-\mathrm{NHC}$ complex $3 \mathrm{a}$, compared to $100 \%$ for $\mathrm{K}_{2} \mathrm{CO}_{3}$.

As mentioned above, one advantage of performing reactions in flow over conventional batch reactions is that scale up can be achieved simply by running the reactor for longer periods. To test this for our flow reactor we repeated the synthesis of $\mathrm{Au}(\mathrm{I})-\mathrm{NHC}$ complex $3 \mathrm{a}$ at $12.5 \times$ scale (see Experimental), using identical reaction parameters. As expected, analysis of the collected solution showed $100 \%$ conversion to $3 \mathrm{a}$, and $0.521 \mathrm{~g}$ of pure $\mathrm{Au}(\mathrm{I})$-NHC complex $3 \mathrm{a}$ was isolated in $95 \%$ yield (Table 1 , entry 11$)$.

To compare our flow reaction with the conventional batch reaction we conducted the reaction of imidazolium chloride 1a with $\mathrm{Me}_{2} \mathrm{SAuCl}$ in both the commonly used single-phase system, as well as our two-phase reaction system (Scheme 4).
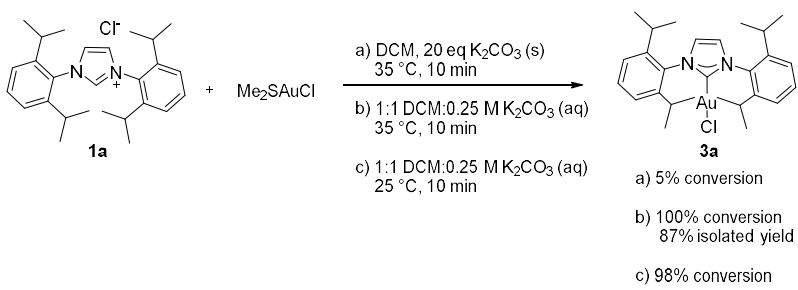

Scheme 4: Batch synthesis of Au(I)-NHC complex 3a in a) single-phase b), c) two-phase solvent systems.

Performing the reaction in just DCM, with 20 eq of $\mathrm{K}_{2} \mathrm{CO}_{3}$ as base, led to extremely poor conversion. Only $5 \%$ conversion (Scheme 4a) was observed after $10 \mathrm{~min}$ at $35^{\circ} \mathrm{C}$ (c.f. $100 \%$ in the two-phase flow reaction). Meanwhile, the two-phase batch reaction also gave full conversion to $\mathrm{Au}(\mathrm{I})-\mathrm{NHC}$ complex 3a under otherwise identical reaction conditions (Scheme 4b) but resulted in a reduced isolated yield of $87 \%$ (c.f. $98 \%$ for the two-phase flow reaction). The two-phase batch reaction at room temperature is also effective, giving $98 \%$ conversion (Scheme 4c). The reason for this dramatic increase in reaction rate with the two-phase system is likely due to more efficient mixing between the aurate salt $\mathbf{2 a}$ and the base in the two-phase system compared to the heterogeneous reaction. Comparing the two-phase flow and batch reactions, the batch reaction resulted in greater decomposition of the $\mathrm{Au}(\mathrm{I})-\mathrm{NHC}$ complex; within minutes the aqueous phase had turned a dark grey and under evaporation of the separated organic phase the resulting solid was grey, requiring a silica plug filtration to acquire the pure gold complex. In the flow reaction, however, both the phases remained clear and colourless throughout. Evaporation of the 
organic phase resulted immediately in a white solid product which was shown to be pure $\mathrm{Au}(\mathrm{I})$-NHC complex $\mathbf{3 a}$, according to ${ }^{1} \mathrm{H}$ NMR spectroscopy. Whilst we do not fully understand the mechanism behind this improvement, as the decomposition of $\mathrm{Au}(\mathrm{I})$ to $\mathrm{Au}(0)$ in such syntheses is poorly understood, we suggest that the more uniform and efficient phase mixing offered by the microfluidic flow reactor is likely to be a factor. The advantage that this brings in the reduction of necessary workup, as well as the inherent scalability of the flow reaction, is likely to be useful in environments where $\mathrm{Au}(\mathrm{I})-\mathrm{NHC}$ complexes are synthesised regularly.

$\mathrm{Au}(\mathrm{III})-\mathrm{NHC}$ complexes are readily available from $\mathrm{Au}(\mathrm{I})-\mathrm{NHC}$ complexes via oxidation by $\mathrm{PhICl}_{2}{ }^{22}$ We envisioned an easy route towards $\mathrm{Au}(\mathrm{III})$ - NHC complexes by adding a second reaction step to our flow apparatus, oxidising the formed $\mathrm{Au}(\mathrm{I})$ $\mathrm{NHC}$ complex without isolation. A schematic of the second reaction stage is shown in Figure 2, and a schematic of the full two-stage reactor is shown in Figure S4. The single-step reactor used for synthesis of the Au(I)-NHC complexes 3a-g was extended by connecting an input port of a second $y$-shaped mixer $\mathrm{Y} 2$ to the separator's side channel $\mathbf{S}$. A third syringe (S3) containing a DCM solution of the oxidant $\mathrm{PhICl}_{2}$ was connected to the second input port of $\mathrm{Y} 2$. The output port of $\mathrm{Y} 2$ was connected to a second $5 \mathrm{~m}$ length of tubing (Zone B), which was kept at $35^{\circ} \mathrm{C}$ by submersion in the same water bath as the tubing in Zone $\mathrm{A}$. The flow rate from $\mathrm{S} 3$ was set at $100 \mu \mathrm{l} / \mathrm{min}$, generating a continuous flow in Zone B with a flow rate of 300 $\mu \mathrm{l} / \mathrm{min}$, corresponding to a residence time of $13.1 \mathrm{~min}$. Here, the $\mathrm{Au}(\mathrm{I})-\mathrm{NHC}$ complex $\mathbf{3 a}$ emitted from the separator at $\mathbf{S}$ is oxidised by $\mathrm{PhICl}_{2}$ to form the $\mathrm{Au}(\mathrm{III})-\mathrm{NHC}$ complex 4a, which is collected after passing through Zone $\mathrm{B}$. The reaction is shown in Scheme 5.

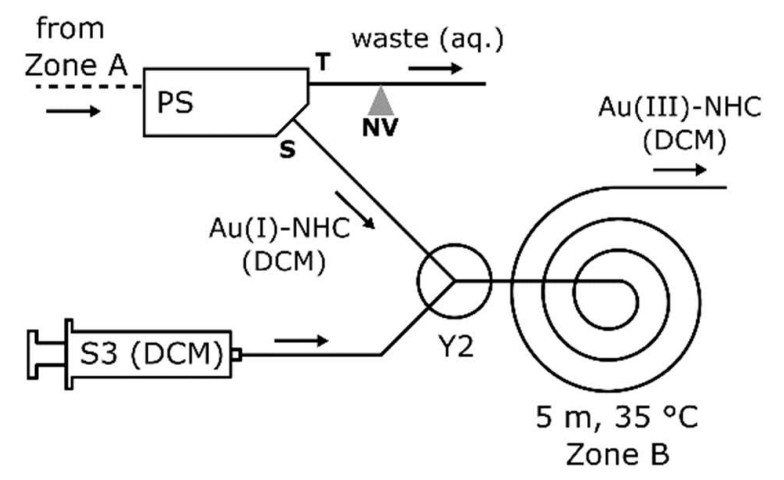

Figure 2. Schematic of second stage of the flow reactor used for synthesis of the Au(III)-NHC complex 4a. The first stage of the reactor consists of the single-step reactor used for synthesising the Au(I)-NHC complexes 3a-g (see Figures 1 and S4). The DCM stream emitted from S, containing the Au(I)-NHC complex 3a is directed into one input of a second y-shaped mixer Y2. A DCM solution of the oxidant $\mathrm{PhICl}_{2}$ is injected into the other input port from a third syringe (S3), forming a continuous flow which enters a second $5 \mathrm{~m}$ length of tubing (Zone B). The oxidised Au(III)-NHC complex 4a is collected at the output of Zone B.

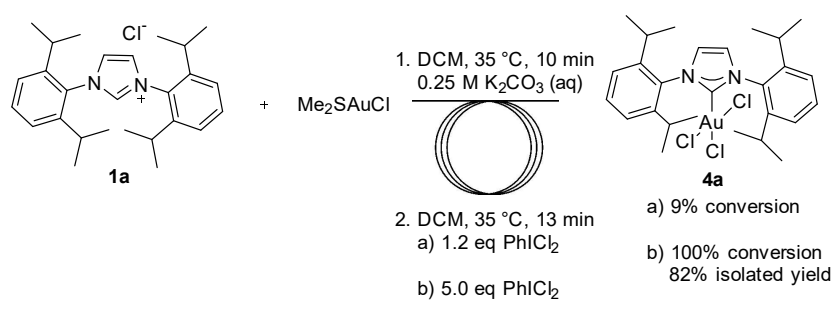

Scheme 5: Synthesis of $\mathrm{Au}(\mathrm{III})-\mathrm{NHC}$ complex 4a directly from imidazolium salt 1a in the two-stage flow reactor described in Figure 2.

Performing the reaction with 1.2 equiv. $\mathrm{PhICl}_{2}$ (Scheme 5a) led to poor conversion (9\%) to the $\mathrm{Au}(\mathrm{III})$ complex $4 \mathrm{a}$, as determined by ${ }^{1} \mathrm{H}$ NMR. However, increasing the amount of oxidant to 5 equiv. (Scheme $5 \mathrm{~b}$ ) gave a $100 \%$ conversion and gave $\mathrm{Au}(\mathrm{III})-\mathrm{NHC}$ complex $4 \mathrm{a}$ in $82 \%$ isolated yield for the two-step reaction. This two-stage reactor therefore greatly simplifies the synthesis of $4 \mathrm{a}$ from the starting imidazolium salt $1 \mathrm{a}$ - once the reactor is started, the $\mathrm{Au}(\mathrm{III})-\mathrm{NHC}$ complex $4 \mathrm{a}$ can be collected after around 25 minutes, without isolation or purification of any intermediates. The only workup required is washing of the acquired solid product $4 \mathbf{a}$ with pentane and filtration through a short silica plug.

\section{Conclusions}


In summary, we have presented a simple and efficient route to $\mathrm{Au}(\mathrm{I})-\mathrm{NHC}$ complexes from imidazolium salts by use of a twophase version of the weak base route under segmented flow conditions. The flow reactor consists of a small number of lowcost parts, including a syringe pump, mixer, separator block, and a few low-cost fittings, making it simple to construct without significant outlay. The method allows the synthesis of the most common $\mathrm{Au}(\mathrm{I})-\mathrm{NHC}$ complexes under mild conditions and short reaction times. The important benefits of the flow conditions are reduced decomposition to elemental gold, simple scalability, and minimal workup, with only evaporation needed to acquire the $100 \%$ pure $\mathrm{Au}(\mathrm{I})-\mathrm{NHC}$ complexes. This method is excellent for both imidazolium and imidazolinium chlorides with bulky groups, but is less effective for $N, N$ dialkylbenzimidazolium chlorides and ineffective for less hindered $\mathrm{N}, \mathrm{N}$-dialkylimidazolium chlorides. We have also shown that performing the coordination in a two-phase $\mathrm{H}_{2} \mathrm{O}: \mathrm{DCM}$ system greatly increases the reaction rate for the bulk reaction (performed outside of segmented flow conditions).

The flow reaction was expanded to include a second, oxidation step. This allowed for the synthesis of a Au(III)-NHC complex directly from the parent imidazolium salt, without isolation or purification of the intermediate $\mathrm{Au}(\mathrm{I}) \mathrm{complex}$. This proves to be a rapid and user-friendly approach towards $\mathrm{Au}(\mathrm{III})$-NHC complexes, making research into their properties more accessible.

We believe this method provides simple access to Au-NHC complexes of importance to both catalysis and medicinal chemistry, and could potentially be applied to the synthesis of NHC complexes of other metals.

\section{Author Contributions}

HFJ and AJH conceived the study, performed experiments, and wrote the manuscript. HFJ analysed data. AF assisted with conceptualisation and reviewed the manuscript.

\section{Conflicts of interest}

There are no conflicts of interest to declare.

\section{Experimental}

\section{General}

Commercial grade reagents were used without any additional purification. $1 \mathrm{H}$ NMR spectra were recorded using a Bruker Avance DPX $400 \mathrm{MHz}$ spectrometer in $\mathrm{CDCl} 3$ as the solvent. Chemical shifts are reported in ppm ( $\delta)$ downfield from tetramethylsilane (TMS) as an internal standard. 1-mm inner diameter, 2-mm outer diameter PTFE tubing (228-4118,VWR) was used for all external tubing. Porous PTFE (Aeos ePTFE) with an inner diameter of 1.8 $\mathrm{mm}$, an outer diameter of $2.5 \mathrm{~mm}$ and an internodal distance of $15-25 \mu \mathrm{m}$ was used inside the liquid-liquid phase separator. All connections were made with standard nut-and-ferrule type connectors. The back-pressure at the separator's through-outlet T was controlled using a PEEK micro-metering needle valve (Rheodyne XP-230). Diagrams detailing designs of and connections to the phase separator and the y-mixers are shown in Figures S1 and S2 (see SI). All liquids were pumped from $10 \mathrm{ml}$ syringes (Hamilton GASTIGHT) mounted within dual-channel syringe pumps (Harvard PHD2000).

\section{General procedure for the flow synthesis of $\mathrm{Au}(\mathrm{I})$-NHC complexes}

Prior to each experimental run, the reactor was flushed with clean distilled water and DCM to remove any traces of products from previous runs. The water bath used to control the temperatures of tubing zones $A$ and $B$ was set to $35^{\circ} \mathrm{C}$, and the temperature was allowed to stabilise. $0.012 \mathrm{M}$ solutions of aurate salts $2 \mathrm{a}-\mathrm{g}$ were formed by dissolving $0.0706 \mathrm{mmol}$ of the NHC-preligands $1 \mathrm{a}-\mathrm{g}$ and $\mathrm{Me} \mathrm{S}_{2} \mathrm{SACC}$ in $6 \mathrm{ml}$ of DCM and sonicating for 5 minutes. The aurate solution, as well as $6 \mathrm{ml}$ of $0.25 \mathrm{M}$ aqueous $\mathrm{K}_{2} \mathrm{CO}_{3}$ solution were loaded into syringes $\mathrm{S} 1$ and S2 respectively, and the pumps were started. Collection of reaction products was started after one full volume of stable segmented flow had passed through the reactor, and continued until the delivery syringes were nearly empty. The syringes were then filled with blank solvent, and the pumps restarted until the dead volume of the reactor had been fully flushed into the collection flasks. Evaporation of the collected organic phase under reduced pressure afforded the pure $\mathrm{Au}(\mathrm{I})-\mathrm{NHC}$ complexes $3 a-e$ as white solids.

$\mathrm{Au}(\mathrm{I})-\mathrm{NHC}$ complex $3 \mathrm{a}$ 
According to the general procedure for the flow synthesis of $\mathrm{Au}(\mathrm{I})-\mathrm{NHC}$ complexes, NHC-preligand $1 \mathrm{a}$ (30.0 mg, $0.0706 \mathrm{mmol}$ ) and $\mathrm{Me}_{2} \mathrm{SAuCl}(20.8 \mathrm{mg}, 0.0706 \mathrm{mmol}$ ) gave $\mathrm{Au}(\mathrm{I})-\mathrm{NHC}$ complex $3 \mathrm{a}$ as a white solid in $98 \%$ yield (43.1 $\mathrm{mg}, 0.0692 \mathrm{mmol}) .{ }^{1} \mathrm{H}$ NMR $\left(400 \mathrm{MHZ}, \mathrm{CDCl}_{3}\right) \mathrm{d}(\mathrm{ppm}) 7.50(\mathrm{t}, \mathrm{J}=7.8 \mathrm{~Hz}, 2 \mathrm{H}), 7.29(\mathrm{~d}, \mathrm{~J}=7.8 \mathrm{~Hz}, 4 \mathrm{H}), 7.17(\mathrm{~s}, 2 \mathrm{H})$, 2.56 (sept, J = 7.0 Hz, 4H), 1.34 (d, J = 7.0 Hz, 12H), $1.22(\mathrm{~d}, \mathrm{~J}=7.0 \mathrm{~Hz}, 12 \mathrm{H}) .{ }^{13} \mathrm{C} \mathrm{NMR}\left(150 \mathrm{MHZ}, \mathrm{CDCl}_{3}\right) \mathrm{d}(\mathrm{ppm}) 175.5$

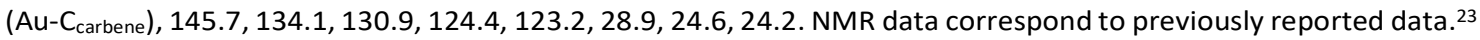
$\mathrm{Au}(\mathrm{I})-\mathrm{NHC}$ complex 3b

According to the general procedure for the flow synthesis of $\mathrm{Au}(\mathrm{I})-\mathrm{NHC}$ complexes, NHC-preligand $\mathbf{1 b}(24.1 \mathrm{mg}$, $0.0706 \mathrm{mmol}$ ) and $\mathrm{Me}_{2} \mathrm{SAuCl}(20.8 \mathrm{mg}, 0.0706 \mathrm{mmol}$ ) gave $\mathrm{Au}(\mathrm{I})-\mathrm{NHC}$ complex $3 \mathrm{~b}$ as a white solid in $88 \%$ yield (33.5 $\mathrm{mg}, 0.0621 \mathrm{mmol}) .{ }^{1} \mathrm{H}$ NMR $\left(400 \mathrm{MHZ}, \mathrm{CDCl}_{3}\right) \delta(\mathrm{ppm}) 7.09(\mathrm{~s}, 2 \mathrm{H}), 6.99(\mathrm{~s}, 4 \mathrm{H}), 2.34(\mathrm{~s}, 6 \mathrm{H}), 2.10(\mathrm{~s}, 12 \mathrm{H}) .{ }^{13} \mathrm{C} \mathrm{NMR}$ $\left(150 \mathrm{MHZ}, \mathrm{CDCl}_{3}\right.$ ) $\delta(\mathrm{ppm}) 173.4$ (Au- $\left.\mathrm{C}_{\text {carbene }}\right), 139.9,134.8,134.75,129.6,122.3,21.3,17.9$. NMR data correspond to previously reported data. ${ }^{23}$

\section{$\mathrm{Au}(\mathrm{I})-\mathrm{NHC}$ complex $3 \mathrm{c}$}

According to the general procedure for the flow synthesis of $\mathrm{Au}(\mathrm{I})$-NHC complexes, NHC-preligand 1c ( $30.2 \mathrm{mg}$, $0.0706 \mathrm{mmol}$ ) and $\mathrm{Me}_{2} \mathrm{SAuCl}(20.8 \mathrm{mg}, 0.0706 \mathrm{mmol}$ ) gave $\mathrm{Au}(\mathrm{I})-\mathrm{NHC}$ complex $3 \mathrm{c}$ as a white solid in $90 \%$ yield (39.3 $\mathrm{mg}, 0.0635 \mathrm{mmol}) .{ }^{1} \mathrm{H}$ NMR $\left(600 \mathrm{MHZ}, \mathrm{CDCl}_{3}\right) \delta(\mathrm{ppm}) 7.41(\mathrm{t}, \mathrm{J}=7.8 \mathrm{~Hz}, 2 \mathrm{H}), 7.23(\mathrm{~d}, \mathrm{~J}=7.8 \mathrm{~Hz}, 4 \mathrm{H}), 4.04(\mathrm{~s}, 4 \mathrm{H})$, 3.05 (sept, J = 6.9 Hz, 4H), $1.41(\mathrm{~d}, \mathrm{~J}=6.8 \mathrm{~Hz}, 12 \mathrm{H}), 1.33(\mathrm{~d}, \mathrm{~J}=6.9 \mathrm{~Hz}, 12 \mathrm{H}) .{ }^{13} \mathrm{C} \mathrm{NMR}\left(150 \mathrm{MHZ}, \mathrm{CDCl}_{3}\right) \delta(\mathrm{ppm}) 196.2$ (Au- Carbene) $_{\text {c }} 146.7,134.2,130.2,124.8,53.6,29.1,25.3,24.3$. NMR data correspond to previously reported data. ${ }^{23}$ Au(I)-NHC complex 3d

According to the general procedure for the flow synthesis of $\mathrm{Au}(\mathrm{I})-\mathrm{NHC}$ complexes, NHC-preligand $1 \mathrm{~d}(24.2 \mathrm{mg}$, $0.0706 \mathrm{mmol}$ ) and $\mathrm{Me}_{2} \mathrm{SAuCl}(20.8 \mathrm{mg}, 0.0706 \mathrm{mmol}$ ) gave $\mathrm{Au}(\mathrm{I})-\mathrm{NHC}$ complex $3 \mathrm{~d}$ as a white solid in $88 \%$ yield (33.5 $\mathrm{mg}, 0.0621 \mathrm{mmol}) .{ }^{1} \mathrm{H} \mathrm{NMR}\left(400 \mathrm{MHZ}, \mathrm{CDCl}_{3}\right) \delta(\mathrm{ppm}) 6.94(\mathrm{~s}, 4 \mathrm{H}), 3.98(\mathrm{~s}, 4 \mathrm{H}), 2.31(\mathrm{~s}, 12 \mathrm{H}), 2.29(\mathrm{~s}, 6 \mathrm{H}) .{ }^{13} \mathrm{C} \mathrm{NMR}$ $\left(100 \mathrm{MHZ}, \mathrm{CDCl}_{3}\right) \delta(\mathrm{ppm}) 195.0$ (Au-C carbene $_{\text {) }}$ 139.0, 135.6, 134.7, 129.9, 50.8, 21.2, 18.1. NMR data correspond to previously reported data. ${ }^{23}$

\section{$\mathrm{Au}(\mathrm{I})-\mathrm{NHC}$ complex $3 \mathrm{e}$}

According to the general procedure for the flow synthesis of $\mathrm{Au}(\mathrm{I})$-NHC complexes, NHC-preligand 1e $(24.4 \mathrm{mg}$, $0.0706 \mathrm{mmol}$ ) and $\mathrm{Me}_{2} \mathrm{SAuCl}(20.8 \mathrm{mg}, 0.0706 \mathrm{mmol}$ ) gave $\mathrm{Au}(\mathrm{I})-\mathrm{NHC}$ complex 3e as a white solid in $94 \%$ yield (35.9 $\mathrm{mg}, 0.0664 \mathrm{mmol}) .{ }^{1} \mathrm{H}$ NMR $\left(400 \mathrm{MHZ}, \mathrm{CDCl}_{3}\right) \delta(\mathrm{ppm}) 7.36-7.43(\mathrm{~m}, 5 \mathrm{H}), 6.91(\mathrm{~s}, 2 \mathrm{H}), 5.93(\mathrm{dd}, \mathrm{J}=8.6,5.4 \mathrm{~Hz}, 1 \mathrm{H})$, 4.23-4.33 (m, 2H), 3.88-3.95 (m, 1H), 3.77-3.84 (m, 1H), 3.65-3.72 (m, 1H), 3.48-3.55 (m, 1H), $2.30(\mathrm{dd}, \mathrm{J}=7.2,5.6$ $\mathrm{Hz}, 1 \mathrm{H}, \mathrm{OH}), 2.29(\mathrm{~s}, 3 \mathrm{H}), 2.23(\mathrm{~s}, 3 \mathrm{H}), 2.20(\mathrm{~s}, 3 \mathrm{H}) .{ }^{13} \mathrm{C} \mathrm{NMR}\left(150 \mathrm{MHZ}, \mathrm{CDCl}_{3}\right) \delta(\mathrm{ppm}) 194.0$ (Au-C $\left.\mathrm{C}_{\text {carbene }}\right), 138.9$, $136.1,135.6,135.4,135.1,129.8,129.7,129.2,128.8,127.5,64.1,61.2,50.6,44.9,21.2,18.3,18.2$. NMR data correspond to previously reported data. ${ }^{13}$

\section{$\mathrm{Au}(\mathrm{I})$-NHC complex $3 \mathrm{~g}$}

$\mathrm{NHC}$-preligand $1 \mathrm{~g}(18.8 \mathrm{mg}, 0.0706 \mathrm{mmol})$ and $\mathrm{Me}_{2} \mathrm{SAuCl}(20.8 \mathrm{mg}, 0.0706 \mathrm{mmol})$ were dissolved in $6 \mathrm{ml}^{\text {of }} \mathrm{CHCl}_{3}$ and sonicated for 5 minutes to form a $0.012 \mathrm{M}$ solution of aurate intermediate $2 \mathrm{~g}$. The aurate solution and $6 \mathrm{ml}$ of a $0.25 \mathrm{M}$ solution of aqueous $\mathrm{K}_{2} \mathrm{CO}_{3}$ were then loaded into their respective syringes. The flow reactor was run at 53 ${ }^{\circ} \mathrm{C}$ with a flow rate of $100 \mu \mathrm{l} / \mathrm{min}$ (residence time approx. $20 \mathrm{~min}$ ) and the organic phase was collected. Evaporation under reduced pressure gave $\mathrm{Au}(\mathrm{I})-\mathrm{NHC}$ complex $\mathbf{3 g}$ in $93 \%$ purity as a yellow solid in $21 \%$ yield $(7.3 \mathrm{mg}, 0.0148$ mmol). ${ }^{1} \mathrm{H}$ NMR $\left(400 \mathrm{MHZ}, \mathrm{CDCl}_{3}\right) \delta(\mathrm{ppm})$ 7.89-7.92 (m, 2H), 7.30-7.32 (m, 2H), $2.18(\mathrm{~s}, 18 \mathrm{H}) .{ }^{13} \mathrm{C} \mathrm{NMR}(150 \mathrm{MHZ}$, $\mathrm{CDCl}_{3}$ ) 177.0 (Au- $\mathrm{C}_{\text {carbene }}$ ), 134.0, 123.0, 116.2, 61.8, 32.9. NMR data correspond to previously reported data. ${ }^{20}$

\section{Scaled up flow synthesis of $\mathrm{Au}(\mathrm{I})-\mathrm{NHC}$ complex $3 \mathrm{a}$}

NHC-preligand 1a (375 mg, $0.882 \mathrm{mmol}$ ) and $\mathrm{Me}_{2} \mathrm{SAuCl}(260 \mathrm{mg}, 0.882 \mathrm{mmol}$ ) were dissolved in $75 \mathrm{ml}$ of DCM and sonicated for 5 minutes to form a $0.012 \mathrm{M}$ solution of aurate $2 \mathrm{a}$. The aurate solution and $75 \mathrm{ml}$ of a $0.25 \mathrm{M}$ aqueous $\mathrm{K}_{2} \mathrm{CO}_{3}$ were then loaded into their respective syringes. The flow reaction was then performed as described in the general procedure. The collected organic phase was dried over anhydrous $\mathrm{Na}_{2} \mathrm{SO}_{4}$, filtered and dried under reduced pressure to give $\mathrm{Au}(\mathrm{I})-\mathrm{NHC}$ complex $3 \mathrm{a}$ as a white solid in $95 \%$ yield ( $521 \mathrm{mg}, 0.839 \mathrm{mmol}$ ).

\section{Single-Phase Batch Synthesis of $\mathrm{Au}(\mathrm{I})$-NHC Complex 3a}

$\mathrm{NHC}$ preligand 1a $(30.0 \mathrm{mg}, 0.0706 \mathrm{mmol})$ and $\mathrm{Me}_{2} \mathrm{SAuCl}(20.8 \mathrm{mg}, 0.0706 \mathrm{mmol})$ were dissolved in $6 \mathrm{ml} \mathrm{DCM}$ and stirred for 5 minutes at $35^{\circ} \mathrm{C}$ to form a $0.012 \mathrm{M}$ solution of the $\mathrm{NHC}$-aurate $2 \mathrm{a} . \mathrm{K}_{2} \mathrm{CO}_{3}(195 \mathrm{mg}, 0.141 \mathrm{mmol})$ was then added. The resulting suspension stirred for 10 minutes at $35{ }^{\circ} \mathrm{C}$ after which it was filtered through celite. The solvent was evaporated under reduced pressure and the conversion to Au(I)-NHC complex 3 a was determined by ${ }^{1} \mathrm{H}$ NMR spectroscopy.

\section{Two-Phase Batch Synthesis of Au(I)-NHC Complex 3a}

NHC-preligand (1a, $30.0 \mathrm{mg}, 0.0706 \mathrm{mmol})$ and $\mathrm{Me}_{2} \mathrm{SAuCl}(20.8 \mathrm{mg}, 0.0706 \mathrm{mmol})$ were dissolved in $6 \mathrm{ml} \mathrm{DCM}$ and stirred for 5 minutes at $35^{\circ} \mathrm{C}$ to form a $0.012 \mathrm{M}$ solution of the $\mathrm{NHC}$-aurate $2 \mathrm{a} .6 \mathrm{ml}$ of $0.25 \mathrm{M}$ aqueous $\mathrm{K}_{2} \mathrm{CO}_{3}$ solution was added, and the mixture was stirred vigorously for 10 minutes. After completion of the reaction, $10 \mathrm{ml}$ of DCM and $10 \mathrm{ml}$ of brine were added, and the phases separated. The organic phase was dried over anhydrous $\mathrm{Na}_{2} \mathrm{SO}_{4}$ and evaporated under reduced pressure. The resulting mixture was filtered through a short silica plug with 
EtOAc as the eluent to filter off the formed $\mathrm{Au}(0)$. Evaporation yielded the pure $\mathrm{Au}(\mathrm{I})-\mathrm{NHC}$ complex $3 \mathrm{a}$ as a white solid in $87 \%$ yield $(37.9 \mathrm{mg}, 0.0614 \mathrm{mmol}$ ).

Two-step flow synthesis of Au(III)-NHC Complex 4a

The single-stage flow reactor was extended via addition of the hardware for the second oxidation step, see Fig. 2 and Fig. S4. NHC-preligand 1a $(60.0 \mathrm{mg}, 0.141 \mathrm{mmol})$ and $\mathrm{Me}_{2} \mathrm{SAuCl}(41.6 \mathrm{mg}, 0.141 \mathrm{mmol}$ ) were dissolved in $12 \mathrm{ml}$ of DCM and sonicated for 5 minutes to form a $0.012 \mathrm{M}$ solution of aurate $2 \mathrm{a}$. The aurate solution, as well as $12 \mathrm{ml}$ of $0.25 \mathrm{M}$ aqueous $\mathrm{K}_{2} \mathrm{CO}_{3}$ solution were loaded into their respective syringes and the flow reactor was operated as described above. $\mathrm{PhICl}_{2}$ (194.0 mg, $0.706 \mathrm{mmol}$ ) was dissolved in $6 \mathrm{ml}$ of DCM to form a $0.12 \mathrm{M}$ solution and loaded into syringe S3. The pumps for syringes $\mathrm{S} 1$ and $\mathrm{S} 2$ were started first, and the pump for syringe S3 was started after around 10 minutes (just before the $A u(I)$ NHC complex 3a had reached Y2). The organic phase containing the newly formed Au(III)-NHC complex 4a was collected at the reactor outlet, evaporated under reduced pressure and redissolved in a minimal amount of DCM. Pentane was added to induce precipitation and the resulting solid was washed thoroughly with pentane. The washed solid was then filtered through a short silica plug with EtOAc as the eluent to filter off remaining $\mathrm{PhICl}_{2}$. Evaporation under reduced pressure gave $\mathrm{Au}(\mathrm{III})$ $\mathrm{NHC}$ complex $4 \mathrm{a}$ as a yellow solid in $82 \%$ yield $(80.1 \mathrm{mg}, 0.116 \mathrm{mmol}) .{ }^{1} \mathrm{H} \mathrm{NMR}\left(400 \mathrm{MHZ}, \mathrm{CDCl}_{3}\right) \delta(\mathrm{ppm}) 7.56(\mathrm{t}, \mathrm{J}=8.0 \mathrm{~Hz}$, $2 \mathrm{H}), 7.36(\mathrm{~d}, \mathrm{~J}=8.0 \mathrm{~Hz}, 4 \mathrm{H}), 7.34(\mathrm{~s}, 2 \mathrm{H}), 2.85(\mathrm{sept}, \mathrm{J}=6.7 \mathrm{~Hz}, 4 \mathrm{H}), 1.40(\mathrm{~d}, \mathrm{~J}=6.8 \mathrm{~Hz}, 12 \mathrm{H}), 1.13(\mathrm{~d}, \mathrm{~J}=6.8 \mathrm{~Hz}, 12 \mathrm{H}) .{ }^{13} \mathrm{C} \mathrm{NMR}$ $\left(100 \mathrm{MHZ}, \mathrm{CDCl}_{3}\right) \delta(\mathrm{ppm}) 146.2$ (Au- $\left.\mathrm{C}_{\text {carbene) }}\right), 132.3,132.0,126.4,124.9,29.2,26.7,22.9$. NMR data correspond to previously reported data. ${ }^{24}$

\section{References}

1 M. N. Hopkinson, C. Richter, M. Schedler and F. Glorius, Nature, 2014, 510, 485-496.

S. Díez-González, N. Marion and S. P. Nolan, Chem. Rev., 2009, 109, 3612-3676.

N. Marion and S. P. Nolan, Chem. Soc. Rev., 2008, 37, 1776-1782.

M. Michalak and W. Kośnik, Catalysts, 2019, 9, 890.

L. Rocchigiani and M. Bochmann, Chem. Rev., , DOI:10.1021/acs.chemrev.0c00552.

M. Mora, M. C. Gimeno and R. Visbal, Chem. Soc. Rev., 2019, 48, 447-462.

T. Scattolin and S. P. Nolan, Trends Chem., 2020, 2, 721-736.

E. A. Martynova, N. V Tzouras, G. Pisanò, C. S. J. Cazin and S. P. Nolan, Chem. Commun., 2021, 57, 3836-3856.

D. J. Nelson, Eur. J. Inorg. Chem., 2015, 2015, 2012-2027.

A. Collado, A. Gómez-Suárez, A. R. Martin, A. M. Z. Slawin and S. P. Nolan, Chem. Commun., 2013, 49, 5541-5543.

R. Visbal, A. Laguna and M. C. Gimeno, Chem. Commun., 2013, 49, 5642-5644.

N. V Tzouras, F. Nahra, L. Falivene, L. Cavallo, M. Saab, K. Van Hecke, A. Collado, C. J. Collett, A. D. Smith, C. S. J. Cazin and S. P. Nolan, Chem. - A Eur. J., 2020, 26, 4515-4519.

H. F. Jónsson, A. Orthaber and A. Fiksdahl, Dalt. Trans., 2021, 50, 5128-5138.

M. B. Plutschack, B. Pieber, K. Gilmore and P. H. Seeberger, Chem. Rev., 2017, 117, 11796-11893.

A. Adamo, P. L. Heider, N. Weeranoppanant and K. F. Jensen, Ind. Eng. Chem. Res., 2013, 52, 10802-10808.

A. J. Harvie, J. O. Herrington and J. C. DeMello, React. Chem. Eng., 2019, 4, 1579-1588.

J. H. Bannock, S. H. Krishnadasan, M. Heeney and J. C. de Mello, Mater. Horiz., 2014, 1, 373-378.

A. Simoens, T. Scattolin, T. Cauwenbergh, G. Pisanò, C. S. J. Cazin, C. V Stevens and S. P. Nolan, Chem. - A Eur. J., 2021, 27, 5653-5657.

A. Johnson and M. C. Gimeno, Chem. Commun., 2016, 52, 9664-9667.

S. Gonell, M. Poyatos and E. Peris, Angew. Chemie Int. Ed., 2013, 52, 7009-7013.

T. Scattolin, N. V Tzouras, L. Falivene, L. Cavallo and S. P. Nolan, Dalt. Trans., 2020, 49, 9694-9700.

P. de Frémont, R. Singh, E. D. Stevens, J. L. Petersen and S. P. Nolan, Organometallics, 2007, 26, 1376-1385.

P. de Frémont, N. M. Scott, E. D. Stevens and S. P. Nolan, Organometallics, 2005, 24, 2411-2418.

S. Gaillard, A. M. Z. Slawin, A. T. Bonura, E. D. Stevens and S. P. Nolan, Organometallics, 2010, 29, 394-402. 